\title{
United States considers drug stockpile
}

$\mathrm{T}$ he United States keeps massive stockpiles of strategic materials for extraordinary threats: medicines in the event of terrorist attack, oil in case world supplies go haywire, gold to counter economic calamity, nuclear weapons for the ultimate war.

It's been caught off guard, however, by the everyday need for common, vital drugs.

Facing a growing shortage of drugs for chemotherapy, infections and other severe conditions, the government is considering establishing a pharmaceutical Fort Knox, a national repository for must-have cancer meds that people are finding it ever harder to get.

Proposals are also in play to give the US Food and Drug Administration (FDA) more influence in the supply chain, which these days often begins abroad at manufacturing plants out of sight of US inspectors. Contamination and other manufacturing defects are held responsible for part of the historic shortage. As well, slim profit margins for older and generic medications are persuading drug companies to drop production for those in favour of more lucrative drugs.

At least 15 deaths have been blamed on the shortage, which the FDA says have nearly tripled since 2005 , exceeding 170 drugs last year and worsening in 2011 (www.fda.gov/drugs/drugsafety /drugshortages/ucm050792.htm). Many hospitals are turning to the gray market for supplies and are often paying the price in terms of extreme mark-ups.

In Vero Beach, Florida, Dr. William T. McGarry gave away two treasured tickets to a Florida-Auburn college football game to secure drugs need to treat a patient's treatable lymphoma. "For her, a treatment delay would have been terrible," he says.

His patients, many of them single parents on government health insurance, have experienced delays of up to a week in needed care, while he and office staff chase suppliers, ware-

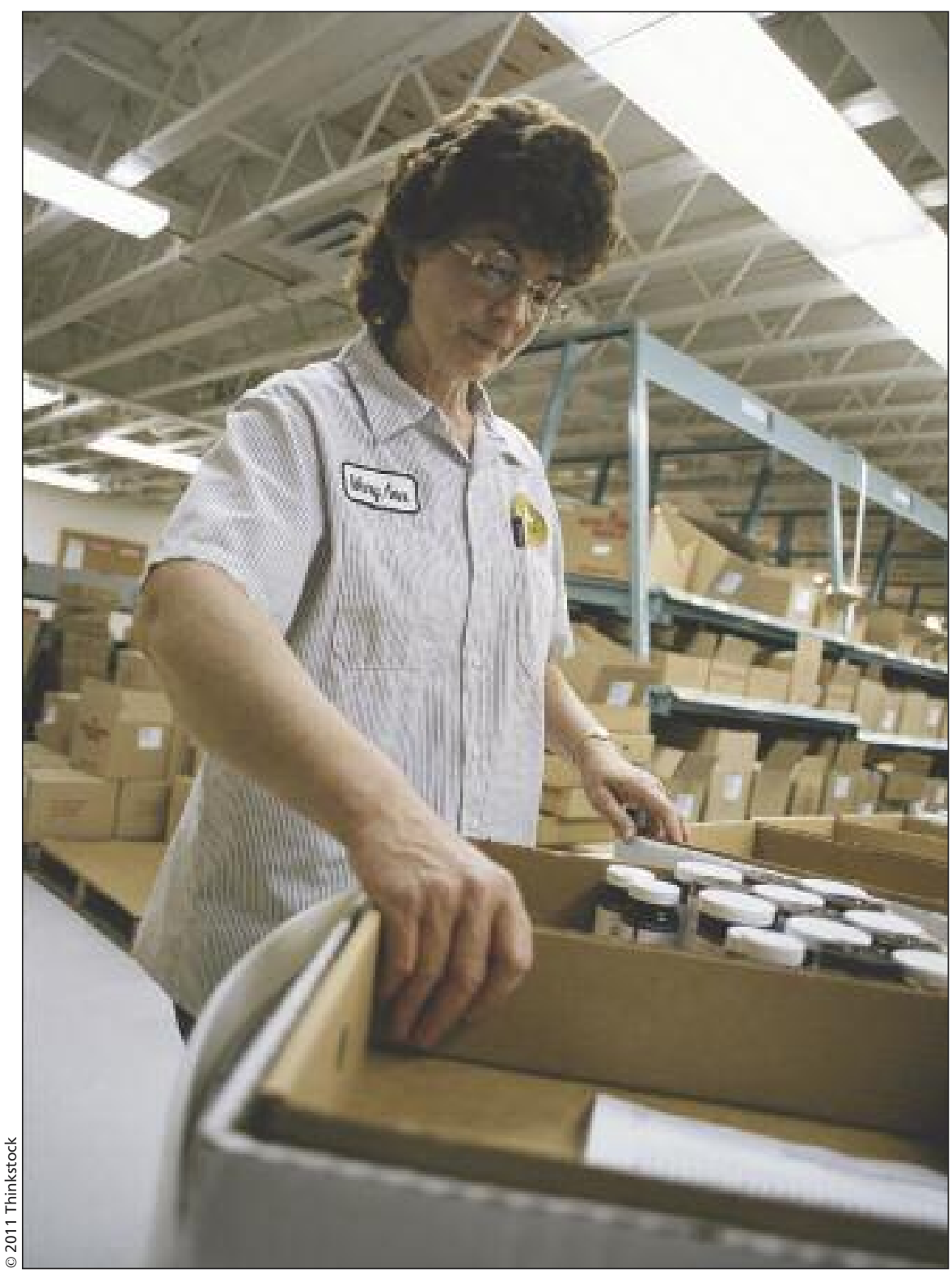

US drug warehouses would be stocked by a nonprofit company whose mission would be to import medicines deemed to be in short supply.

houses, hospitals and any other avenue they can think of to get drugs.

"It's been a nightmare for the past two-three years and it's getting worse," McGarry says. "I've been trying to make these problems invisible [for patients]. They don't need to have more worries. They've been stoic and understanding. They haven't been anywhere near as frustrated as I am."
And anxiety-ridden patients are, understandably, not always patient.

"They panic," says Dr. Shayma Kazmi, an oncologist and hematologist with the Cancer Treatment Centers of America in Philadelphia, Pennsylvania, a network of four regional destination hospitals. "First they learn they have cancer, then they have to do chemotherapy, then they hear they may not be 
able to get chemotherapy - it's a lot of anxiety. Like they need anything else to be anxious about."

Kazmi's team track shortages and try to get their 250 or so patients on priority lists for drugs, when they become available. "We do what we can to avoid having a clinical disaster. We get creative" by, for example, administering docetaxel instead of the workhorse cancer drug paclitaxel, even though it may not be the best choice. "It makes you think about the availability of the drug, not just the therapeutic aspect of it."

In response to the shortages, President Barack Obama's administration has floated the notion of creating a cancer-drug storehouse resembling the existing National Pharmaceutical Stockpile, which hoards antibiotics, vaccines and medical supplies for deployment in the event of bioterrorism, earthquakes or epidemics. Under one option, according to published reports, the government would obtain and store dry ingredients for cancer drugs and, in a shortage, distribute them to pharmacists to mix into injectable compounds.

Political allies in Congress are intrigued, although some are skeptical about maintaining a varied, ever-changing and narrowly targeted inventory of drugs. In addition, leading oncologists have formed a nonprofit company with the hope of importing and eventually making the cancer drugs most in need.

Legislators have introduced bills to set up an early warning system by requiring drugmakers to report anticipated shortages to the FDA. They've also proposed spending nearly US $\$ 300$ million to bolster inspection of foreign drug plants, which are largely in China and India.

The political climate for higher spending and increased regulation is notably inhospitable, however, particularly in the wake of the US having narrowly averted catastrophic defaults on debt payments just two months ago. And with Obama having put the US on track toward universal health coverage, anything that smacks of further centralization of government authority is viewed with distaste in the Republicancontrolled House of Representatives. Some argue that overzealous regulation is a prime barrier to economic recovery and a particular menace to the medical industry. Others even say that the short- age, itself, is the product of a regulatory blizzard that stifles production and scares off new manufacturers.

That debate also plays out in physician's offices. Kazmi, for one, thinks a national stockpile could be a valuable tool, while McGarry declares: "I think the government is the problem. I'm suspicious. They can stockpile the drugs, then we'll have to beg the government to get them."

Costs, meanwhile, continue to climb. The Premier Healthcare Alliance, an association of 2500 hospitals and about 76000 other health facilities, found that the gray market was marking up drug prices by an average of $650 \%$ (www.premierinc.com/about /news/11-aug/Gray-Market/Gray-Market -Analysis-08152011.pdf).

And creative workarounds can have tragic results. Alabama authorities reported that 9 patients recently died and 10 got sick from contamination of handmixed liquid nutrition administered through feeding tubes. The sterile, manufactured product could not be obtained. - Cal Woodward, Washington, DC

CMAJ 2011. DOI:10.1503/cmaj.109-4018 